\title{
POLA SEGREGASI DAN HERITABILITAS SIFAT KETAHANAN KEDELAI TERHADAP COWPEA MILD MOTTLE VIRUS POPULASI WILIS X MLG2521
}

\author{
Maimun Barmawi ${ }^{1}$
}

\begin{abstract}
Segregation and Heritability of Cowpea Mild Mottle Virus Resistant Characters of Soybean Genotypes from Crosses Between Wilis and Mlg2521 Population. This research was conducted within July to October, 2005 at experiment station of Lampung University. The aims of this research were to evaluate the segreation and heritability of resitant characters at $F_{2}$ population of Wilis x Mlg2521. The result showed that segregation of resistant characters segretate 13:3 of succeptible and resistant genotypes. Heritability in the narrow sense based on disease severity was 13,18\% (low) and heritabilitas heritability in the broad-sense was $80,91 \%$ (high).
\end{abstract}

Key wods: Cowpea Mild Mottle Virus, soybean, segregation, heratability

\section{PENDAHULUAN}

Kendala biologi dalam budidaya kedelai adalah epidemi penyakit dan merupakan penyebab rendahnya produktivitas kedelai di Indonesia. Salah satu penyakit penting utama yang menjadi kendala dalam budidaya kedelai adalah penyakit yang disebabkan oleh CPMMV (cowpea mild mottle virus). Tanaman yang terserang CPMMV akan mengalami penurunan hasil $11-56 \%$ (Akin, 2003).

Penggunaan kultivar unggul yang tahan terhadap CPMMV dengan daya hasil yang tinggi merupakan alternatif pengendalian penyakit yang penting dan tidak menimbulkan dampak negatif seperti penggunaan insektisida. Kultivar tanaman yang tahan dapat dikembangkan melalui penerapan teknik pemuliaan tanaman konvensional jika gen ketahanannya ada dalam plasma nutfah kedelai; atau dengan memakai pendekatan rekayasa genetika jika gen ketahanannya tidak ditemukan pada populasi kedelai.

Sampai saat ini belum ada kultivar unggul kedelai yang tahan terhadap CPMMV. Pengendalian penyakit hanya dengan aplikasi insektisida untuk mengendalikan serangga vektor. Namun, masalah penyakit ini masih belum bisa diatasi dengan efektif. Penggunaan insektisida mempunyai beberapa kelemahan seperti adanya residu senyawa bahan aktif yang persisten, timbulnya resistensi serangga sasaran, terbunuhnya organisme bukan sasaran, dan menyebabkan terjadinya resugensi, yaitu munculnya populasi hama yang kepadatannya jauh lebih tinggi beberapa kali lipat.
Hasil evaluasi ketahanan beberapa genotipe kedelai di Lampung terdapat tingkat keragaman ketahanan kultivar kedelai terhadap serangan CPMMV (Akin, 2003). Hasil penyaringan tersebut diperoleh kultivar yang bereaksi tahan yaitu galur Mlg2521. Keadaan ini menunjukkan bahwa terdapat peluang untuk perbaikan genetika karakter ketahanan terhadap CPMMV melalui persilangan dengan yang tahan. Hasil persilangan akan menghasilkan populasipopulasi zuriat yang memiliki keragaman genetika ketahanan yang luas dan disertai dengan berbagai karakter agronomi yang diinginkan.

Pengetahuan tentang pola pewarisan sifat ketahanan terhadap CPMMV merupakan hal penting untuk diketahui dalam rangka pengembangan kultivar melalui persilangan-persilangan. Pola pewarisan dan pendugaan jumlah gen yang terlibat dapat diduga dari sebaran frekuensi genotipe pada generasi $\mathrm{F}_{2}$; pada generasi ini terjadi segregasi dan rekombinasi yang luas (Christiana, 1996).

Adanya keragaman genetik yang luas memberikan kesempatan kepada pemulia untuk dapat melakukan seleksi. Seleksi adalah suatu proses pemuliaan tanaman dan merupakan dasar dari seluruh perbaikan tanaman untuk mendapatkan kultivar unggul baru. Keberhasilan seleksi tergantung pada kemampuan pemulia untuk memisahkan genotipegenotipe unggul dari genotipe yang tidak dikehendaki. Bagaimana cara membedakan antara genotipe unggul dengan genotipe yang tidak unggul atas dasar penilaian fenotipe individu atau kelompok tanaman yang dievaluasi diperlukan pertimbangan tentang besaran beberapa parameter genetik. Beberapa parameter genetik yang dapat digunakan sebagai

\footnotetext{
${ }^{1}$ Dosen Jurusan Budidaya Pertanian Fakultas Pertanian Universitas Lampung, Kampus Gedung Meneng, Bandar lampung 35145
} 
pertimbangan supaya seleksi efektif misalnya besaran nilai keragaman genetik, heritabilitas, pola segregasi, jumlah gen, dan aksi gen pengendali karakter yang menjadi perhatian.

Seleksi suatu karakter yang diinginkan akan lebih berarti jika karakter tersebut mudah diwariskan. Mudah tidaknya pewarisan suatu karakter dapat diketahui dari besar nilai heritabilitasnya. Tujuan Penelitian mengetahui pola segregasi populasi $\mathrm{F}_{2}$ apakah sejalan dengan nisbah Mendel dan menentukan besaran nilai heritabilitas sifat ketahanan kedelai terhadap CPMMV.

\section{METODE PENELITIAN}

Percobaan dilaksanakan di kebun percobaan Universitas Lampung dari bulan Juli sampai dengan Oktober 2005. Perlakuan diisusun dalam Rancangan Kelompok Teracak Sempurna dengan dua ulangan. Setiap ulangan terdiri atas 20 populasi $\mathrm{P}_{1} ; 20$ populasi $\mathrm{P}_{2} ; 20$ populasi $\mathrm{F}_{1} ; 35$ populasi $\mathrm{F}_{2} ; 7$ populasi $\mathrm{BC}_{1}$; dan 13 populasi $\mathrm{BC}_{2}$. Pengujian kesesuaian antar nilai pengamatan dan nilai harapan digunakan uji Khi-Kuadrat yang tergantung dari banyaknya kelas (Gomez \& Gomez, 1995).

a) Dua kelas

$$
\chi^{2}=\sum_{j=1}^{n} \frac{\left(\left|0_{j}-E_{j}\right|-0.5\right)^{2}}{E_{j}}
$$

b) Lebih dua kelas

$$
\chi^{2}=\sum_{j=1}^{n} \frac{\left(0_{j}-E_{j}\right)^{2}}{E_{j}}
$$

$\mathrm{j} \quad=1,2,3, \ldots, \mathrm{n}$

$\mathrm{DK}=\mathrm{n}-1$

$\mathrm{O}_{\mathrm{j}} \quad$ = jumlah pengamatan dalam kelas ke- $\mathrm{j}$

$\mathrm{E}_{\mathrm{j}} \quad=$ jumlah pengamatan yang diharapkan dalam kelas ke-j.

Model pewarisan sifat ketahanan, data pengamatan dikelompokkan menjadi beberapa kategori ketahanan yang dianalisis pada setiap populasi generasi $\mathrm{F}_{2}$. Menurut Snyder \& David (1957), jika distribusi penampilan populasi $F_{2}$ menunjukkan

(1) Dua puncak: maka kemungkinannya mengikuti nisbah $3: 1$ (dominan sempurna), 9: 7 (epistasis resesif duplikat), $15: 1$ (epistasis dominan duplikat), atau $13: 3$ (epistasis dominan resesif).

(2) Tiga puncak, kemungkinannya mengikuti nisbah 1: $2: 1$ (dominan tidak sempurna), $9: 3: 4$ (epistasis resesif), $9: 6: 1$ (duplikat dengan efek kumulatif), atau $12: 3: 1$ (epistasis dominan).

(3) Lebih dari tiga puncak, kemungkinan mengikuti nisbah $9: 3: 3: 1$ (koepistasis) atau nisbah Mendel model digenik (1:4:6:4:1) trigenik $(1: 6: 15: 20: 15: 6: 1)$.

(4) Bentuk unimodal, maka segregasi yang terjadi adalah poligenik.

Hipotesis pertama $\left(\mathrm{H}_{0}\right)$ menduga bahwa pola segregasi ketahanan terhadap serangan CPMMV sesuai dengan hukum Mendel atau modifikasinya; dengan demikian $\mathrm{H}_{0}$ diterima bila $\chi_{\text {hitung }}^{2}<\chi_{\text {tabel }}^{2}$. Lawan dari hipotesis tersebut $\left(\mathrm{H}_{1}\right)$ menduga bahwa pola segregasi ketahanan terhadap serangan CPMMV tidak sesuai dengan hukum Mendel atau modifikasinya.

Pendugaan heritabilitas dalam arti sempit dan arti luas didasarkan rumus yang dikemukakan Simmond (1979), yaitu :

$$
\begin{aligned}
& \sigma_{E}^{2}=\frac{\sigma_{P_{1}}^{2}+\sigma_{P 2}^{2}+\sigma_{F_{1}}^{2}}{3} \\
& \sigma_{F_{2}}^{2}=\sigma_{A}^{2}+\sigma_{D}^{2}+\sigma_{E}^{2} \\
& \sigma_{B C 1}^{2}=\sigma_{B C 2}^{2}=\sigma_{A}^{2}+2 \sigma_{D}^{2}+2 \sigma_{E}^{2} \\
& h_{S}^{2}=\frac{\sigma_{A}^{2}}{\sigma_{A}^{2}+\sigma_{D}^{2}+\sigma_{E}^{2}} \\
& h_{L}^{2}=\frac{\sigma_{A}^{2}+\sigma_{D}^{2}}{\sigma^{2}{ }_{A}+\sigma_{D}^{2}{ }_{D}+\sigma_{E}^{2}}
\end{aligned}
$$

$$
\text { Keterangan : } \begin{aligned}
h_{S}^{2} & =\text { Heritabilitas arti sempit } \\
h_{L}^{2} & =\text { Heritabilitas arti luas } \\
\sigma^{2}{ }_{P_{1}} & =\text { Varians fenotifik } \mathrm{P}_{1} \\
\sigma^{2}{ }_{P_{2}} & =\text { Varians fenotifik } \mathrm{P}_{2} \\
\sigma^{2} F_{1} & =\text { Varians fenotifik } \mathrm{F}_{1} \\
\sigma^{2} F_{2} & =\text { Varians fenotifik } \mathrm{F}_{2} \\
\sigma_{A}^{2} & =\text { Varians aditif } \\
\sigma_{E}^{2} & =\text { Varians lingkungan } \\
\sigma^{2}{ }_{D} & =\text { Varians dominan }
\end{aligned}
$$


Kedelai ditanam pada petak percobaan berukuran $6 \times 3 \mathrm{~m}$ dengan jarak tanam $15 \times 30 \mathrm{~cm}$, menggunakan 2 petak besar. Di dalam setiap petak terdiri atas 7 baris dan masing-masing baris terdiri atas 15 lubang tanam.

Perbanyakan CPMMV dilakukan pada tanaman kedelai. Tanaman kedelai yang menimbulkan gejala kemudian digunakan sebagai sumber inokulum. Inokulum CPMMV diperoleh dari daun kedelai terinfeksi. Daun tersebut kemudian digerus dalam mortar dan diberi bufer fosfat dengan pH $7(1: 9 \mathrm{w} / \mathrm{v})$ lalu disaring dengan kain kasa.

Tanaman yang diinokulasi CPMMV berumur 10 hari setelah tanam. Inokulasi dilakukan secara mekanik pada bagian atas permukaan daun kedelai yang sebelumnya ditaburkan karborundum 600 mesh. Inokulasi dilakukan dengan mengoleskan sap tanaman yang mengandung CPMMV dengan menggunakan kapas pada tiap-tiap daun kedelai.

Tanaman umur tujuh hari setelah tanam dipupuk dengan urea dosis $50 \mathrm{~kg} / \mathrm{ha}, \mathrm{SP}-36$ dan $\mathrm{KCl} 100$ $\mathrm{kg} / \mathrm{ha}$. Pemberian pupuk dilakukan dengan cara membuat lubang $\pm 15 \mathrm{~cm}$ dari lubang tanam dan pemberian urea dipisahkan dari lubang SP-36 dan $\mathrm{KCl}$. Untuk mencegah serangan kutu daun yang dapat menjadi vektor virus dilakukan penyemprotan dengan insektisida Decis 2,5 EC setiap satu minggu.

Peubah yang diamati yaitu adalah periode inkubasi penyakit yang dihitung dari waktu inokulasi sampai timbulnya gejala penyakit. Keparahan penyakit yang diamati pada 10 contoh daun trifololiatus tanaman kedelai yang telah membuka sempurna yang diawali dari daun paling atas. Pengamatan keparahan penyakit dilakukan pada saat tanaman berumur 28 hari setelah inokulasi. Keparahan penyakit dihitung menggunakan rumus:

$$
K P=\frac{\sum(n x v)}{N x Z} x 100 \%
$$

KP : Keparahan penyakit; n: Jumlah sampel untuk kategori serangan

$\mathrm{v} \quad$ : Nilai skor untuk kategori serangan

$\mathrm{N} \quad$ : Jumlah sampel yang diamati

$\mathrm{Z} \quad$ : Nilai skor tertinggi.

Skor gejala penyakit dikelompokkan menurut Akin (2005, komunikasi pribadi):

Skor 0 : Tidak ada gejala;

Skor 1 : Khlorosis dan tulang daun memucat;

Skor 2 : Gejala mosaik dengan khlorosis pada tulang daun dan permukaan daun;

Skor 3 : Mosaik berat, permukaan daun bergelom bang, dan tepi daun melengkung ke atas

Skor 4 : Malformasi daun.

Berdasarkan nilai KP masing-masing famili dikelompokkan menjadi Tahan, jika $0 \% \leq \mathrm{KP} \leq 15 \%$; Agak Tahan, jika $16 \% \leq \mathrm{KP} \leq 25 \%$; Agak rentan, jika $26 \% \leq \mathrm{KP} \leq 35 \%$; Rentan, jika $36 \% \leq \mathrm{KP} \leq 55 \%$; dan Sangat Rentan, jika 56\% $\leq \mathrm{KP} \leq 100 \%$.

\section{HASIL DAN PEMBAHASAN}

Hasil pengamatan periode inkubasi penyakit akibat infeksi CPMMV terpendek adalah populasi $\mathrm{P}_{1}$ (Wilis) dan terpanjang populasi $\mathrm{F}_{2}$ dan $\mathrm{BC}_{1}$ (Tabel 1). Pendugaan heritabilitas dalam percobaan ini menggunakan perhitungan heritabilitas dalam arti luas dan arti sempit sesuai dengan rumus yang diajukan oleh Simmond (1979), yang disajikan pada Tabel 2.

Tabel 1. Rata-rata periode inkubasi dan keparahan penyakit pada pengamatan kedua

\begin{tabular}{lcc}
\hline Populasi & $\begin{array}{c}\text { Periode } \\
\text { Inkubasi (Hari) }\end{array}$ & $\begin{array}{c}\text { Keparahan } \\
\text { Penyakit pada 28 hsi }\end{array}$ \\
\hline $\mathrm{P}_{1}$ (Wilis) & 6 & 61,42 \\
$\mathrm{P}_{2}$ (Mlg2521) & 10 & 50,17 \\
$\mathrm{~F}_{1}$ (Wilis X Mlg2521) & 10 & 41,47 \\
$\mathrm{~F}_{2}$ (Wilis X Mlg2521) & 16 & 40,98 \\
$\mathrm{BC}_{1}$ (Wilis X Mlg2521) X Wilis & 16 & 24,85 \\
$\mathrm{BC}_{2}$ (Wilis X Mlg2521) X Mlg2521 & 14 & 26,53 \\
\hline
\end{tabular}


Tabel 2. Nilai duga heritabilitas dalam arti sempit keparahan penyakit

\begin{tabular}{cc}
\hline Komponen Varians & Wilis X Mlg 2521 (\%) \\
\hline$\sigma^{2} \mathrm{P}_{1}$ & 63,67 \\
$\sigma^{2} \mathrm{P}_{2}$ & 36,74 \\
$\sigma^{2} \mathrm{~F}_{1}$ & 71,15 \\
$\sigma^{2} \mathrm{~F}_{2}$ & 299,60 \\
$\sigma^{2} \mathrm{BC}_{1}$ & 78,97 \\
$\sigma^{2} \mathrm{BC}_{2}$ & 74,89 \\
\hline$\sigma^{2} \mathrm{~A}$ & 39,5 \\
$\sigma^{2} \mathrm{D}$ & 202,92 \\
$\sigma^{2} \mathrm{E}$ & 57,18 \\
\hline$h_{S}^{2}$ & 13,18 \\
$h_{L}^{2}$ & 80,91
\end{tabular}

Nilai duga heritabilitas dalam arti luas lebih tinggi dibandingkan dengan nilai heritabilitas dalam arti sempit. McWhirter (1979) membagi heritabilitas ke dalam tiga kelas yaitu rendah $(\leq 0,2)$, sedang $\left(0,2<h_{S}^{2} \leq 0,5\right)$, dan tinggi $(>0,5)$. Dari penghitungan dengan metode Simmond diperoleh nilai duga heritabilitas dalam arti sempit sebesar 13,18\% termasuk kategori rendah; sedangkan untuk nilai heritabilitas dalam arti luas diperoleh nilai sebesar $80,91 \%$ (tinggi).

Berdasarkan nilai duga heritabilitas dalam arti sempit yang rendah untuk sifat ketahanan kedelai berindikasi bahwa varians genetik aditif untuk karakter tersebut adalah rendah; sebalikknya ragam genetik genetik nonaditif tinggi. Oleh karena itu, sifat ketahanan tanaman kedelai terhadap CPMMV tidak mudah diwariskan dari tetua kepada keturunannya.

Tingkat ketahanan kedelai terhadap CPMMV dapat diidentifikasi dengan penilaian secara visual berdasarkan skor daun pada penghitungan keparahan penyakit (KP). Hasil analisis pola segregasi karakter KP dapat dilihat pada Tabel 3.

Dari Tabel 3 menunjukkan bahwa pola segregasi populasi $\mathrm{F}_{2}$ pada persilangan Wilis x Mlg 2521 sesuai harapan $(\alpha 0,05)$ untuk nisbah $3: 1,13: 3,1: 2: 1$, dan $9: 6: 1$. Namun tampak bahwa pola segregasi dengan nisbah $13: 3$ mempunyai peluang yang paling besar yaitu $(\mathrm{P}=75 \%-90 \%)$, sehingag pola segregasi populasi $F_{2}$ mengikuti nisbah $13: 3$. Hal ini berarti bahwa karakter tersebut dikendalikan oleh gen yang bereaksi epistasis dominan resesif (Synder \& David, 1957).

Pola segregasi populasi $F_{2}$ untuk karakter keparahan penyakit pada persilangan Wilis x Mlg 2521 mengikuti nisbah 13 (rentan) : 3 (tahan) yang bereaksi epistasis dominan resesif, artinya gen dominan epistasis terhadap gen dominan dan resesif yang bukan sealel dan gen resesif epistasis terhadap gen dominan dan resesif yang bukan sealel. Dari uraian tersebut dapat disimpulkan bahwa efek aksi gen nonaditif (dominan dan epistasis) berperan dalam mengendalikan karakter ketahanan penyakit akibat infeksi CPMMV.

Berdasarkan hasil pendugaan nilai heritabilitas dan pola segregasi, maka seleksi untuk mendapatkan tanaman yang tahan terhadap serangan CPMMV tidak bisa dilakukan pada generasi awal karena pada generasi awal tingkat heterozigositasnya masih tinggi. Untuk mendapatkan tanaman yang benar-benar memiliki ketahanan terhadap serangan CPMMV sulit. Bila seleksi dilakukan pada generasi-generasi selanjutnya diharapkan tingkat homozigositas zuriatzuriat dalam populasi yang bersangkutan adalah tinggi sehingga seleksi akan lebih mudah dan dapat dilakukan uji ketahanan terhadap CPMMV.

\section{SIMPULAN}

Pola segregasi ketahanan kedelai terhadap serangan CPMMV untuk populasi F2 pada 
Tabel 3. Uji khi-kuadrat pada segregasi karakter keparahan penyakit populasi $F_{2}$ (Wilis X Mlg 2521) yang terinfeksi CPMMV

\begin{tabular}{|c|c|c|c|c|c|}
\hline Nisbah KP & $\begin{array}{c}\text { Pengamatan } \\
(\mathrm{O})\end{array}$ & $\begin{array}{l}\text { Harapan } \\
\text { (E) }\end{array}$ & $\chi^{2} h$ & $\chi^{2} 0,05$ & Peluang (\%) \\
\hline \multicolumn{6}{|l|}{ Dua Kelas } \\
\hline \multicolumn{6}{|l|}{ Rentan:Tahan } \\
\hline $3: 1$ & $25: 6$ & $23,25: 7,75$ & $0,720^{\operatorname{tn}}$ & & $50-25$ \\
\hline $9: 7$ & $25: 6$ & $17,44: 13,56$ & $7,653^{*}$ & 3,84 & $<5$ \\
\hline $13: 3$ & $25: 6$ & $25,19: 5,81$ & $0,036^{\mathrm{tn}}$ & & $90-75$ \\
\hline $15: 1$ & $25: 6$ & $29,06: 1,94$ & $7,266^{*}$ & & $<5$ \\
\hline \multicolumn{6}{|l|}{ TigaKelas } \\
\hline \multicolumn{6}{|l|}{$\overline{\text { Rentan:Agak }}$} \\
\hline \multicolumn{6}{|l|}{ Rentan:Tahan } \\
\hline $1: 2: 1$ & $13: 12: 6$ & $7,75: 15,50: 7,75$ & $4,596^{\mathrm{tn}}$ & & $25-10$ \\
\hline $9: 3: 4$ & $13: 12: 6$ & $7,75: 5,81: 17,44$ & $7,617^{*}$ & 5,99 & $<5$ \\
\hline $9: 6: 1$ & $13: 12: 6$ & $1,94: 11,62: 17,44$ & $2,053^{\text {tn }}$ & 11,1 & $50-25$ \\
\hline $12: 3: 1$ & $13: 12: 6$ & $1,94: 5,81: 23,25$ & 89 & & $<5$ \\
\hline
\end{tabular}

Keterangan: $\quad * \quad$ : nyata pada $\alpha 0,05$

tn : tidak nyata

persilangan Wilis X Mlg 2521 mengikuti pola segregasi $13: 3$. Heritabilitas dalam arti sempit untuk karakter keparahan penyakit akibat infeksi CPMMV yaitu sebesar $13,18 \%$ (rendah) dan untuk nilai duga heritabilitas dalam arti luas diperoleh nilai sebesar $80,91 \%$ (tinggi).

Seleksi tidak dapat dilakukan pada generasi awal karena $h_{S}^{2}$ rendah yang berarti bahwa karakter ketahanan kedelai terhadap CPMMV dikendalikan oleh aksi gen nonaditif (dominan dan epistasis). Oleh sebab itu seleksi disarankan pada generasi $F_{5}$ atau $F_{6}$ yang ditanam dalam jumlah banyak.

\section{SANWACANA}

Penelitian ini didanai oleh Hibah Bersaing XII Ditjen Dikti Depdiknas. Atas dukungan tersebut diucapkan terima kasih. Ucapan terima kasih juga disampaikan kepada Dr. Hasriadi Mat Akin, Dr. Setyo Dwi Utomo, dan Yusi Fitri Muchsi, S.P. atas bantuan dalam pelaksanaan penelitian dan penulisan naskah ini.

\section{DAFTAR PUSTAKA}

Akin, H. M. 2003. Respons Beberapa Genetik Kedelai terhadap Infeksi CPMMV (Cowpea
Mild Mottled Virus). Jurnal Hama dan Penyakit Tumbuhan Tropika. 3(2) : 40-42.

Christiana, A. L. 1996. Pewarisan Sifat Ketahanan Kedelai terhadap Serangan Ophyomia phaseoli Tryon di Dalam Kurungan Kasa. Skripsi. Universitas Padjajaran. Bandung. 64 hlm.

Gomez, A. K., \& A. A. Gomez. 1995. Prosedur Statistik Untuk Penelitian. Diterjemahkan oleh E. Syamsuddin dan J.S. Baharsyah. Edisi Kedua. Penerbit Universitas Indonesia

McWhirter, K.S. 1979. Breeding of Cross-Pollinated Crops: Selection Methods for Improving Cross-Pollinating Plant Species. In: Plant Breeding. R. Knight (ed.). Academy Press Pty. Ptd., Brisbane

Simmonds, N.W. 1979. Principles of Crops Improvement. Logman Group Limited. London.

Synder, L. H. \& P. R. David. 1957. The Principles of Heredity. Health Company. Boston. 